\title{
Tying in International Trade: Evidence on Countertrade
}

\author{
Dalia Marin
}

\section{INTRODUCTION}

\begin{abstract}
$\mathbb{1}$ OUNTERTRADE is tied trade. In a typical transaction a CPE or LDC imports goods and the exporting party - usually a firm in a western industrial country - commits itself to make an offsetting purchase at some future date. Since the mid seventies countertrade has become a significant phenomenon in international trade. Reasonable estimates vary between 10 and 20 per cent of world trade (see OECD, 1985; 1981). ${ }^{1}$ Countertrade takes three main forms: barter, counterpurchase and buy-back. ${ }^{2}$ The three forms all entail linked exportimport transactions, but they differ from each other in terms of whether they involve foreign exchange in the transaction, whether the two trade flows are temporally separated, and whether the trade flows stand in a technical relation to each other. Barter is a spot transaction in which the two trade flows occur at more or less the same time with no involvement of foreign exchange. Counterpurchase and buy-back, on the other hand, are long-term contracts with the two trade flows taking place at different points in time. Additionally, counterpurchase and buyback involve financially separate transactions in which each trade flow is paid for in hard currency. In buy-back agreements the original export consists of a plant or technology and the repurchase of some portion of the output produced by that equipment, whereas in barter and counterpurchase there is no technical association between the original export and the offsetting purchase.
\end{abstract}

DALIA MARIN is from the Institute for Advanced Studies, Department of Economics, Stumpergasse, Vienna, Italy, and from the Centre for Economic Policy Research. She is indebted to Carl Hamilton and Alan Winters for helpful suggestions on an earlier draft of the paper and to Angela Köppl for excellent research assistance. All remaining shortcomings are those of the author, and none of the individuals mentioned are responsible for the views expressed in this paper.

${ }^{1}$ Generally trade statistics do not give information on whether the transaction has been an untied or a tied export-import transaction which makes estimates of countertrade extremely unreliable.

${ }^{2}$ A fourth form of countertrade - industrial offsets - which take place among industrialized countries is not covered in this paper. In an offset deal the exporter of military hardware or civilian aircraft is requested to source parts in the importing country. 
The growing importance of countertrade in international trade has started to attract the attention of international organisations who view countertrade as a return to bilateralism and reciprocity, and thus as a threat to the multilateral world trading system. This view is partly reflected in the fact that some forms of countertrade are being negotiated under the heading 'trade-related investment measures (TRIMs)' in the Uruguay Round ${ }^{3}$ (Greenaway, 1990; and Guisinger, 1987). Whether countertrade is indeed an inefficient form of exchange will depend on whether or not any extra benefits from tying trade flows can be identified. Despite the prevalence of tying practices in East-West trade and North-South trade, however, the economics and empirics of countertrade is still in its infancy. ${ }^{4}$

This paper tries to fill this gap by providing an empirical analysis of countertrade based on 230 transactions whose details were collected from trading house and firms involved in countertrade. Section 2 describes the data base and states the stylised facts of countertrade that need to be explained. Section 3 gives a critical review of the most frequent explanations of countertrade and confronts them with the data. In Section 4 I examine whether evidence of the theoretical gains from tying trade flows can be found in the data. The potential gains from tying considered in this section are those generated by restoring price flexibility in the presence of some market distortions, and those generated by preventing contractual hazards associated with information asymmetry and ex-post bilateral monopoly. Section 5 discusses the implications of the findings of the paper for trade policy and the GATT.

\section{THE DATA}

The data base consists of a sample of 230 completed countertrade agreements from international trading companies and producers in Vienna active in countertrade. The sample has been generated by a survey in which the respondent (a countertrade specialist) has been asked to provide information on 40 aspects on one specific countertrade transaction. On average three countertrade agreements per firm have been investigated. Ninety per cent of the agreements covered took place between 1984 and 1988. In each agreement I distinguish between the developed country firm called 'DC-firm' who exports to a CPE/LDC and the countertrade partner called 'CPE/LDC-party'. The 'DC-firm' is typically either a producer or a subsidiary of a multinational enterprise located in Austria with its own inhouse countertrade division or a firm in a western industrialised country

\footnotetext{
${ }^{3}$ For earlier discussions on countertrade and the GATT see Gadbaw (1983) and Czinkota (1987).

4 Exceptions are Amann and Marin $(1989,1990)$. Chan and Hoy (1990), and Parsons (1985) who all argue that countertrade is a response to market distortions, information asymmetry, moral-hazard agency problems and incomplete markets. For the descriptive countertrade literature see OECD (1981, 1985), Korth (1987), Group of Thirty (1985). Economic Commission for Europe (1983).
} 
who uses an international trading firm in Vienna to fulfill its countertrade purchasing obligation. Thirty per cent of the industrial firms are based in the European Community and 62.7 per cent in other industrial countries including Austria, Sweden, Japan, and the USA. The 'CPE/LDC-party' is a state agency in a CPE or LDC (85.2 per cent of the cases), a state-owned enterprise (9.1 per cent), or a private firm ( 5.7 per cent) with which the western firm made the agreement.

\section{a. Trade Patterns}

Table 1 shows the forms of countertrade and their regional distribution. Counterpurchase dominates the other two forms of countertrade ( 76.5 per cent). East-West countertrade accounts for 86.5 per cent of the sample and 13.5 per cent is North-South countertrade which reflects Vienna's role as an intermediary of East-West trade. ${ }^{5}$ It is worth noting that the LDCs tend to use buy-back and barter

\section{TABLE 1}

Countertrade: Forms and Region

\begin{tabular}{llll}
\hline & $C P E ' s$ & $L D C$ 's & Total \\
\hline \multirow{3}{*}{ Barter } & 18 & 8 & \\
& $(69.2)$ & $(30.8)$ & 26 \\
& $(9.0)$ & $(25.8)$ & $(11.3)$ \\
Counterpurchase & 158 & 18 & 176 \\
& $(89.8)$ & $(10.2)$ & $(76.5)$ \\
Buy-Back & $(79.4)$ & $(58.1)$ & \\
& 23 & 5 & $(12.2)$ \\
& $(82.1)$ & $(17.9)$ & \\
Total & $(11.6)$ & $(16.1)$ & 230 \\
& 199 & 31 & $(100.0)$ \\
\hline
\end{tabular}

Note: Numbers without brackets are the absolute number of cases, numbers in brackets are row and column percentages, respectively.

Source: Data Sample of 230 countertrade contracts

\footnotetext{
${ }^{5}$ The data base can be considered to represent the parent population of East-West countertrade since the sample covers a sufficiently large number of cases of all CMEA member countries involved in countertrade. More specifically, 14.8 per cent of the cases are with the USSR, 24.8 per cent with Czechoslovakia, 14.3 per cent with Hungary, 7 per cent with Poland, 4.3 per cent with Rumania, 6.5 per cent with East Germany and Bulgaria, respectively, 6.1 per cent with Yugoslavia, and 0.9 per cent with Albania. That the data base is representative for East-West countertrade seems to be supported also by the evidence given in OECD (1981). The information on those dimensions of countertrade which is available in OECD (1981) is in broad accordance with our data sample. In contrast, among North-South countertrade 5.7 per cent of the cases are with Africa, 3 per cent with Asia, 2.6 per cent with South America, and 2.2 per cent with China. Hence North-South countertrade is not as well represented in the sample.
} 
more frequently than the CPEs, who strongly favour counterpurchase (compare the column percentages 25.8 per cent vs 9.0 per cent for barter, and 16.1 per cent vs 11.6 per cent for buy-back). Table 2 shows that exports from OECD countries to the CPEs/LDCs consist mainly of plant, investment equipment and machinery (71 per cent of exports), while the CPEs/LDCs are quite successful in pushing non-traditional exports through countertrade ( 35.5 per cent of countertrade goods are investment and technical goods). Note also that the export of services (especially labour) is not uncommon among countertrade goods.

TABLE 2

Commodity Structure of Trade Flows

\begin{tabular}{lcr}
\hline & Export goods $^{4}$ & $\begin{array}{c}\text { Countertrade goods }^{5} \\
\text { in per cent }\end{array}$ \\
\hline Plant and equipment & & 0.0 \\
Investment and technical goods $^{2}$ & 14.3 & 35.5 \\
Chemical goods $_{\text {Consumption goods }}$ & 56.6 & 8.2 \\
Basic sector goods & 8.8 & 31.9 \\
Toys and cosmetics & 8.8 & 18.4 \\
Services $^{3}$ & 3.6 & 0.0 \\
Total $^{2}$ & 4.0 & 6.0 \\
\hline
\end{tabular}

'Whole factory including managerial and technical assistance and investment equipment above US\$10 million ${ }^{2}$ Investment equipment valued below US\$ 10 million.

${ }^{3}$ Includes among export goods: know-how, patents and licences; among countertrade goods; labour services and freight.

${ }^{4} \mathrm{OECD}$ exports to CPEs/LDCs.

${ }^{5} \mathrm{CPEs} / \mathrm{LDC}$ s exports to OECD.

Source: Data Sample of 230 countertrade contracts.

\section{b. Tying}

There is a wide variety in the degree to which the two trade flows are tied together. As a measure of the degree of tying I use two indicators: the type of countertrade contract and the size of the compensation ratio. The compensation ratio is the value of repurchase by the DC-firm as a percentage of the original export value. Thus, a compensation ratio of 100 per cent means that the DC-firm makes an offsetting purchase equal value of its original export to the CPE/LDC. The compensation ratio varies between 2 and 400 per cent, as can be seen from Table 3 which looks at the relationship between type of contract and compensation ratio. In almost 50 per cent of the contracts the parties opted for less than complete tying of trade flows by choosing a compensation ratio below 100 per cent. Among countertrade types, the buy back contract exhibits the strongest tie since, besides the technical linkage between the trade flows, buy-backs tend to have repurchase values that are equal or are higher than the original export value ( 75 per cent of all 
buy-back agreements have a compensation ratio of 100 per cent or higher). Likewise, one tends to sign a counterpurchase agreement when desiring only a loose tying of commodity flows ( 59 per cent of all counterpurchase contracts have a compensation ratio below 100 per cent). The null hypothesis of independence between countertrade type and compensation ratio is rejected at the 1 per cent significance level, indicating that the forms of countertrade contract differ significantly in their degree of tying.

TABLE 3

Relationship Between Contract Type and Tying of Trade Flows

\begin{tabular}{lcccc}
\hline Compensation ratio & Barter & Counterpurchase & Buy-Back & Total \\
\hline $2 \%-99 \%$ & 2 & 104 & 7 & 113 \\
& $(7.7)$ & $(59.1)$ & $(25.0)$ & $(49.2)$ \\
$100 \%$ & 18 & 52 & 14 & 84 \\
& $(69.2)$ & $(29.5)$ & $(50.0)$ & $(36.5)$ \\
$101 \%-400 \%$ & 6 & 20 & 7 & 33 \\
& $(23.1)$ & $(11.4)$ & $(25.0)$ & $(14.3)$ \\
Total & 26 & 176 & 28 & 230 \\
& $(11.3)$ & $(76.5)$ & $(12.2)$ & $(100)$ \\
\hline
\end{tabular}

Notes: Numbers without brackets are absolute number of cases; numbers in brackets are column percentages. Chi-Square Value $=33.82$; marginal significance level 0.000 .

Value of repurchase by the DC-firm as a percentage of the export value to the CPEs/LDCs. This figure is calculated as a ratio of values and not of units even in the case of barter since in the barter contract the parties use a foreign currency as a unit of account. 'Ex ante' compensation ratio valued at 'declared' prices, not world prices: see also footnote 2 of Table 4 .

Source: Sample of 230 countertrade contracts.

\section{c. Other Features}

Other basic features of contracts are shown in Table 4 which provides the mean, standard deviation, minimum and maximum values, and a brief description of those dimensions of contract that are dealt with in this paper. The data base shows considerable variation also in other dimensions of contract like value (ranging from US\$ 8400 to US\$ 635 million, and duration (ranging from spot market transactions to long-term contracts of ten-year or even infinite time horizon). More than 50 per cent of the agreements are 'fixed price contracts' with no price adjustment for the countertrade goods over the duration of contract. Penalties for non-fulfilment of the countertrade obligation have been specified between zero and 100 per cent. It is worth noting that in 40 per cent of the transactions the penalty for breach is nil (not shown) indicating the high level of trust of the CPE/LDC-party in the conduct of the DC-firm. The high level of trust is not that 
surprising given that in 65.6 per cent of the cases the DC-firm is familiar to the CPE/LDC-party from previous transactions.

TABLE 4

Some Contract Features

\begin{tabular}{|c|c|c|c|c|c|c|}
\hline \multicolumn{3}{|c|}{ Observations Description } & \multirow{2}{*}{$\begin{array}{c}\text { Mean } \\
1117.9\end{array}$} & \multirow{2}{*}{$\frac{\text { Minimum }}{\mathbf{8 . 4}}$} & \multirow{2}{*}{$\begin{array}{l}\text { Maximum } \\
635.000 .0\end{array}$} & \multirow{2}{*}{$\begin{array}{c}\begin{array}{c}\text { Standard } \\
\text { Deviation }\end{array} \\
47773.4\end{array}$} \\
\hline Contract value & 229 & $\begin{array}{l}\text { export value' } \\
\text { (in US\$ } 1000 \text { ) }\end{array}$ & & & & \\
\hline Compensation ratio & 230 & $\begin{array}{l}\text { value of repurchase in } \\
\text { percent of export value }{ }^{2}\end{array}$ & 71.38 & 2.0 & 400.0 & 51.0 \\
\hline Penalty & 227 & $\begin{array}{l}\text { penalty for breach in } \\
\text { percent of export value }\end{array}$ & 7.15 & 0.0 & 100.0 & 10.70 \\
\hline Contract duration & 230 & $\begin{array}{l}\text { time span for repurchase } \\
\text { (in months) }\end{array}$ & 19.71 & 0.0 & $120, \infty$ & $20.81^{5}$ \\
\hline Risk shifting & 221 & $\begin{array}{l}\text { price and/or quantity } \\
\text { adjustment over contract duration }{ }^{3}\end{array}$ & \multicolumn{2}{|c|}{ fixed price contract; dummy } & \multicolumn{2}{|c|}{$(D=1 ; 56.1$ percent $)$} \\
\hline Familiarity of exporter & 227 & frequency of exporting & \multicolumn{2}{|c|}{ regular exporter; dummy } & \multicolumn{2}{|c|}{$(\mathrm{D}=1 ; 65.6$ per cent $)$} \\
\hline
\end{tabular}

'To the CPEs/LDCs

'Sce footnote 1 of Table 3. The table shows the 'ex ante' compensation ratio which is the ratio that the DC-firm and the LDC/CPE-party agree on in the contract. Ex post - during contract execution - the ratio might turn out to differ from the ex ante ratio depending on the risk shifting features of the contract. When prices and/or quantities of the countertrade goods are renegotiable over the duration of the contract the ex ante and ex post compensation ratios will generally differ

'See Table 7 for details.

${ }^{4}$ Frequency of the DC-firms exporting to the CPE/LDC: scaling: regular - occasional - first time exporter.

Excluding the $\infty$

Source: Data Sample of 230 countertrade contracts.

\section{POPULAR EXPLANATIONS OF COUNTERTRADE}

One of the most frequent explanations of countertrade in the descriptive literature is that it allows countries to overcome the constraint on development imposed by a shortage of hard currency. Countertrade helps to finance imports without the use of hard currency thereby allowing the countries using it to overcome the foreign exchange constraint. A first look at Table 1 immediately reveals that this cannot be the main explanation. It is only barter that eases the need for foreign exchange by avoiding the use of money. In both counterpurchase and buy-back, the importing country typically pays for its goods in hard currency and receives hard currency when delivering the countertrade goods. Thus, the latter two forms cannot address a foreign-exchange shortage. Although barter might indeed reduce the need for hard currency, it accounts only for a small proportion of countertrade (11.3 per cent of total countertrade). If the foreign-exchange shortage were the main explanation of countertrade we would expect barter to be the main form of countertrade and the repurchase value to equal the original export value. In fact, however, counterpurchase and a compensation ratio of less than 100 per cent dominate among countertrade.

Another commonly advanced explanation of countertrade starts with the same phenomenon but reverses the argument. Instead of avoiding foreign exchange, 
countertrade helps to generate it by promoting exports of the countertrading countries. Part of the source of the liquidity crisis in LDCs/CPEs is seen to have been created by increased protectionism in western industrialised countries which resulted in a reduction of foreign exchange earnings from exports. Countertrade is considered to generate additional foreign exchange by helping to overcome entry barriers in western export markets as the import is made contingent on the export of the countertrading country's product. How valid is this argument? Countertrade will promote exports when two conditions are met. First, that countertrade allows the countries imposing it to export goods they could not otherwise export. Second, that the countries can effectively segment the market when countertrade is used to create a new market for an already established product. Sales of the countertrade goods could cause displacement of traditional exports when they are sold at lower prices in the countertrade transaction than in traditional trade, and when the contracts are not endorsed with destiny clauses constraining or prohibiting the selling of the countertrade goods to third markets and third parties.

TABLE 5

Export Promotion ${ }^{1}$

\begin{tabular}{|c|c|c|c|}
\hline $\begin{array}{l}\text { Goods and contract } \\
\text { characteristics }\end{array}$ & & $\begin{array}{l}\qquad L D C / C P E \\
\text { First time/occasional } \\
\text { exporter }\end{array}$ & $\begin{array}{l}\text { Regular } \\
\text { exporter }\end{array}$ \\
\hline \multicolumn{4}{|l|}{ Restriction on sale } \\
\hline yes & & 40.0 & 60.0 \\
\hline no & & 41.1 & 58.9 \\
\hline Marginal significance & 0.88 & & \\
\hline Chi-Square Value & 0.024 & & \\
\hline \multicolumn{4}{|l|}{ Category of countertrade goods } \\
\hline investment/technical goods & & 40.8 & 59.2 \\
\hline chemicals & & 59.1 & 40.9 \\
\hline consumption goods & & 35.1 & 64.9 \\
\hline basic sector goods & & 33.3 & 66.7 \\
\hline services & & 71.4 & 28.6 \\
\hline Marginal significance & 0.105 & & \\
\hline Chi-Square Value & 7.66 & & \\
\hline
\end{tabular}

in percent $^{2}$

Countertrade goods exported for the first time or occasionally

40.2

Higher price in countertrade export

26.6

Lower price in countertrade export

10.6

Restriction on resale

36.8

Countertrade goods differentiated in design/quality ${ }^{3}$

51.8

\footnotetext{
${ }^{1}$ Numbers are row percentages.

${ }^{2}$ Of total countertrade.

${ }^{3}$ Countertrade specialist's judgement of whether the countertrade goods are standardised/differentiated with respect to design and/or quality.

Source: Sample of 230 countertrade contracts.
} 
Whether countertrade has been effective in stimulating the export of nontraditional products is examined in Table 5 . In 40 per cent of the transactions the CPEs/LDCs exported products through countertrade which they have not (or only occasionally) sold in the respective export market before. The table provides evidence also on the second prerequisite for additionality of exports. In 10.6 per cent of the contracts the countertrade goods have been potentially competing with non-tied exports. In order to avoid the displacement of traditional exports the contracts have been furnished with destiny clauses in 36.8 per cent of all countertrade contracts.

The table also looks at whether regularly exported countertrade goods have tended to be more often endorsed with restriction on the resale in order to protect already established markets than when the countertrade goods have been exported for the first time. (One would expect this since goods which are exported for the first time are not potentially competing with non-tied exports. The null of no association between status of countertrade export and resale restriction, however, cannot be rejected at conventional levels. Consumption and basic sector goods have tended to be sold less often by countertrade when the LDC/CPE-party is a first time exporter than when it is a regular one, which is some indication of countertrade pushing non-traditional exports (the relationship is significant at about the 10 per cent level).

Summing up, the empirical evidence presented in this section gives some support for the view that countertrade has helped to stimulate and diversify exports, 35.5 per cent of countertrade goods are investment and technical goods, 51.8 per cent are goods differentiated in design and/or quality, 40.2 per cent of the countertrade goods have not or only occasionally been exported before, and in 36.8 per cent of the cases countertrade has been used as an attempt to create a new market. ${ }^{6}$

Although export promotion through countertrade does seem to be consistent with our data, it still leaves open the question why these countries take recourse to countertrade to stimulate exports when less costly policies are available. If the countries imposing countertrade were to have a comparative disadvantage in marketing their exports, as is often asserted, why don't they purchase marketing services from western trading companies in a traditional unilateral transaction? At first glance, countertrade seems to be a rather inefficient means of marketing a country's exports. The answer to this question is dealt with in the next section.

\footnotetext{
${ }^{6}$ Whether the countries have, in fact, been successful in enforcing destiny clauses in order to secure additionality of exports can, however, not be decided on the basis of the data. Some observers have expressed scepticism about the enforceability of supplemented trade and have, therefore, asserted that countertrade will deflate prices of traditional exports leading to a deterioration of the countertrading countries terms of trade in the long-run, see Goldstein (1984).
} 


\section{ARE THERE GAINS FROM TIED TRADE?}

An answer to the question raised in the previous section must start by explaining why tying trade flows might be a superior way of promoting exports than any alternative. Furthermore, any explanation of tied trade has to account for the contract characteristics given in Tables 1 to 4 . To recall these: first, countertrade tends to be a mid-term to long-term fixed price/quantity contract in which the degree of tying varies considerably (as measured by the compensation ratio). Second, countertrade involves a high share of technology exports to the CPEs/ LDCs and third, among countertrade goods there is a high proportion of products which are differentiated with respect to design and/or quality.

In this section I look at two main possible sources of benefits from linking trade: the presence of market distortions and informational imperfections to which countertrade is a second-best solution. For each of the potential gains I examine whether they are consistent with actual countertrade contracts.

\section{a. Correcting Market Distortions}

In order to look at whether tying arrangements can outperform untied ones I focus first on the factors that create an incentive for countertrade only when the DC-firms and/or countertrade partner's market is non-competitive. The existence of widespread distortions in the form of imperfect competition and collusive agreements creates a second-best environment in which countertrade might induce efficiency gains by correcting deviations from competitive conditions. To illustrate this consider the following two examples. Suppose the countertrade partner is an LDC and a member of an international price agreement (like OPEC or an International Commodity Agreement). Suppose further that the LDC is faced with surplus capacity for whatever reason. Under these circumstances the LDC will want to undercut the cartel price. One way of doing so without openly violating the collusive agreement is to use barter. The LDC sells the countertrade goods at the official price and takes an overpriced good from the DC-firm. The lack of transparency in barter makes it an effective route for chiselling. ${ }^{7}$ Circumventing collusive agreements via countertrade might account for why the LDCs use the barter form of countertrade more frequently than the CPEs (as is shown in Table 1). 83.3 per cent of the agreements in which the CPE/LDC-party is a member of a cartel are signed with LDCs. ${ }^{8}$

\footnotetext{
${ }^{7}$ The argument is analogous to the monopoly reasons for vertical integration, see Tirole (1988). However, here tying allows partners to restore price flexibility, while vertical integration allows the monopolist to exercise monopoly power in a hidden way

${ }^{8}$ In 198410 to 20 per cent of oil exports from OPEC countries are estimated to have been bartered, see Banks (1983).
} 
Another example in which barter becomes attractive is when the market distortion takes the form of the DC-firm being a price discriminating monopolist selling to a CPE/LDC. As is well known the price discriminating monopolist can increase profits by asking different prices from customers with different levels of willingness to pay. Assuming that consumers in LDCs/CPEs have a lower reservation price for western products, and that the DC-firm is constrained in the exercise of its monopoly power, barter allows the monopolist to discriminate in a hidden way by obscuring the effective price from disfavoured customer. From the LDCs/CPEs perspective, barter is a way to extract monopoly rents from the DC-firm. ${ }^{9}$

If price distortion plays a role as a source for barter, I expect to find that the size of the compensation ratio agreed on will vary systematically with the DC-firms' market power and with whether or not the CPE/LDC-party is a member of a cartel or a collusive price agreement. In this case the size of the compensation ratio will be the outcome of a bargaining process reflecting the partners' bargaining power. Table 6 provides evidence on the association between the compensation ratio, the DC-firms' market position, and the status of the CPE/LDC-party. Leading producers tend to have contracts with compensation ratios below 100 per cent (56.6 per cent of all contracts signed with DC-firms that are leading producers have a compensation ratio between 2 and 99 per cent) while the reverse is the case for DC-firms with negligible market shares. The null hypothesis of independence between the compensation ratio and the DC-firms market position is rejected by the Chi-Square test. A similar result is obtained for the DC-firms' competitive conditions (not shown). If the CPE/LDC-party is a member of a cartel the contract is more likely to specify compensation ratios of 100 per cent or above. The relationship is significant at the 5 per cent level.

In barter transactions with no money involvement, the compensation ratio determines the terms of trade of the transaction. A low repurchase value as a percentage of the export value means unfavourable terms of exchange for the DC-firm and favourable ones for the CPE/LDC-party. The results given in Table 6 suggest, therefore, that the greater a party's monopoly profits the worse terms it gets in the countertrade contract. Amann and Marin (1989) give a rationale for this result. In a bargaining game with assymetric information a high DC-firm profit margin signals to the CPE/LDC-party that it can make a less favourable offer to the DC-firm without increasing the probability of the DC-firm rejecting it.

\section{b. Tying as an Incentive Device}

As has been shown in the previous section some form of deviation from competitive conditions can account for tied trade. Viewed in this way tying is a

9 See Amann and Marin (1989); for the price discrimination hypothesis see Caves and Marin (1990). 
vehicle to change the terms of trade. The market distortion hypothesis for countertrade, however, fails to explain why countertrade mostly entails long-term contracts with a low degree of price adjustment over the duration of the agreement, and why in countertrade agreements OECD exports to the CPEs/LDCs include a significantly higher share of technology trade as compared with untied trade to these regions. This suggests that, by itself, the monopoly reason for countertrade is an incomplete explanation.

TABLE 6

Relation Between Market Distortion and Tying

\begin{tabular}{|c|c|c|c|c|}
\hline & & & sation & \\
\hline & & $<100 \%$ & $100 \%$ & $>100 \%$ \\
\hline Countertrade & & 49.1 & 36.5 & 14.3 \\
\hline DC-firms market position & & & & \\
\hline leading producer ${ }^{\prime}$ & 67.0 & 56.6 & 32.9 & 10.5 \\
\hline follower & 9.3 & 38.1 & 52.4 & 9.5 \\
\hline one among many & 23.8 & 35.2 & 37.0 & 27.8 \\
\hline Marginal significance & 0.0050 & & & \\
\hline Chi-Square Value & 14.86 & & & \\
\hline Status of CPE/LDC-party & & & & \\
\hline member of cartel ${ }^{2}$ & 2.6 & 0.0 & 83.3 & 16.7 \\
\hline administered price ${ }^{3}$ & 77.3 & 53.1 & 32.8 & 14.1 \\
\hline none of both & 20.1 & 39.1 & 45.7 & 15.2 \\
\hline Marginal significance & 0.043 & & & \\
\hline Chi-Square Value & 9.83 & & & \\
\hline
\end{tabular}

Note: Numbers are row percentages.

'Countertrade specialist's judgement of whether the DC-firm is a leading producer in terms of market share and/or technology.

2 Oil cartel or commodity agreement.

${ }^{3}$ Regulated prices in agriculture, administered prices in planned economies.

Source: Sample of 230 countertrade contracts.

In this section I look at an alternative rationale for tying trade flows in which countertrade is seen as a response to an incentive problem caused by incomplete contracting in relationships where parties have to make irreversible investments. The partners are 'locked into' the relationship ex post because of investments that have considerably higher value within the relationship than outside it. ${ }^{10}$ This view requires that the parties know at the date of agreement that there will be gains from trade between them to be exploited later. In order to induce the efficient amount of relationship specific investment ex ante these future gains have to be divided properly. If one cannot specify ex ante how the surplus should be divided because

\footnotetext{
${ }^{10}$ Williamson (1985) calls an investment that gives an incentive to stay in the relationship 'asset specificity' and calls the threat by one party of not trading to appropriate a greater share of the surplus after specific investments have been made 'opportunism'. For recent literature see Crawford (1988), Farrell and Shapiro (1989), and Rey and Salanie (1990).
} 
writing a complete contract is not feasible, the division will depend on ex post bargaining positions. Under bilateral monopoly each party will want to appropriate the common surplus, thus threatening the efficient realisation of trade $e x$ post and through it the efficient amount of specific investment ex ante. Transforming the transaction from an untied to a tied one offers safeguards against the possibility of opportunistic behaviour thereby securing the parties the return from their investment in an ex post non-competitive bargaining environment. ${ }^{11}$ In other words, tying may enjoy comparative organisational advantages over more standard forms of untied trade because the parties' commitment to the contract is more credibly signaled by their willingness to accept reciprocai exposure of specialised assets. The offer of hostages - as Williamson (1983) calls it - makes the commitment to the contract credible, thereby mitigating contractual hazards.

In order to see how these problems may arise concretely in the context of countertrade consider the following case. Consider a CPE/LDC that is faced with a shortage of foreign exchange. Given the constraint, the CPE/LDC is more risk averse when deciding what to produce for future exports. It will scrutinise carefully competing choices for the use of productive resources with respect to their prospects of generating future foreign exchange earnings. In this situation futures markets would be valuable since they would provide information on future market conditions for the product that the CPE/LDC considers producing and additionally would offer insurance against random fluctuations in price and demand. By selling the product forward, the CPE/LDC can eliminate the risk from its foreign exchange earnings by having a guaranteed price over the period for which the futures market is open. In this way futures markets guarantee that an investment today is generating foreign exchange earnings in the future, making the present foreign exchange constraint less binding. In the absence of such perfect risk markets the CPE/LDC will look for alternative ways to insure itself against the market risk it faces. The CPE/LDC will make market entry of DC-firms contingent on the provision of a private futures market. The CPE/LDC will negotiate with the DC-firm for a forward contract in which the DC-firm commits itself to purchase at a future date the products that the CPE/LDC considers producing. If the DC-firm agrees to such a contract countertrade serves as an insurance against future price fluctuations and the fact that an agreement is reached will give a signal to the $\mathrm{CPE} / \mathrm{LDC}$ on the future demand for the product. ${ }^{12}$

In order to be able to offer such a contract to the CPE/LDC the DC-firm will need to undertake some upfront investment to build up marketing and distribution channels for the countertrade goods. The reason why the provision of a futures market requires up-front investment on the part of the DC-firm lies in the fact that

"The bargaining position of the parties will no longer be independent from the organisational setting in which it is placed when contracts need to be revised or complemented during execution; see also Klein et al. (1978) and Grossman and Hart (1986) in the context of vertical integration.

12 For countertrade as an insurance contract see Amann and Marin (1990). 
the CPEs/LDCs face a reputational barrier to entry on western markets due to western consumers having incomplete information on the quality of the goods coming from these regions. The bad reputation of goods coming from the CPEs/LDCs will change among western consumers only after having some experience with them. In order to induce western consumers to start to purchase these products the DC-firm will need to undertake special marketing efforts. However, the investment in marketing the countertrade goods exposes the DC-firm to contractual hazards of two kinds. First, the risk averse CPE/LDC who is provided with the insurance will have little incentive to meet the quality requirements for the countertrade goods common in western markets. This will, in turn, threaten the DC-firms profits since lower quality products are harder to sell on world markets at a profitable price. Moreover, the western firm will not be able to separate whether the failure to supply the countertrade goods at western quality standards is due to low effort on the part of the CPE/LDC or due to other circumstances. Thus, information asymmetry creates a control problem by introducing a fundamental trade-off between risk sharing and incentives (see Stiglitz, 1974). Second, the CPE/LDC will have an incentive to remove products which have become established on western markets - due to the DC-firms' marketing efforts - from the countertrade shopping-list, since the DC-firm made a commitment to purchase from the list as it stands at a later date. The western firm who has built up a marketing network for the countertrade goods will, however, be 'locked into' the relationship ex post since it will not easily find alternative uses for its investment. The investment in marketing the countertrade goods has considerably higher value when it stays in the relationship with the CPE/LDC than when it leaves it. Faced with the possibility of 'hold up' the DC-firm will not agree to provide a futures market that requires transaction specific investment.

In order to encourage the DC-firm to undertake special marketing efforts for the countertrade goods which is a prerequisite for its successful introduction on western markets a tying arrangement is signed that guarantees the DC-firm a fair return ex post on its investment in order to induce it ex ante to undertake specific investment. The contract guarantees the DC-firm a fair return on its investment because the tying feature of the agreement will equally expose the CPE/LDC to contractual hazards of the following kind. Typically, the CPE/LDC will buy technology and machinery from the DC-firm in the countertrade contract. As is well known, as a technology seller the DC-firm has private information on the quality of the technology which creates an incentive to supply low quality. ${ }^{13}$ By transforming the transaction from an untied to a tied one and by committing the technology seller to repurchase a portion of the output produced with his technology - as in the buy back contract - the incentive of the technology seller to

\footnotetext{
${ }^{13}$ This has become known as the 'lemons' problem in which good quality is driven out by bad quality, see Akeriof (1970).
} 
supply low and outdated technology is weakened when the quality of countertrade goods will depend on the quality of the delivered technology.

But even if the quality of the technology is common knowledge as is the case for standardised machinery, the CPE/LDC as the technology buyer will still be exposed to another type of contractual hazard of the DC-firm as the technology supplier. The CPE/LDC will depend on the technology seller to reveal and provide technology updates and after sales service once it has purchased the technology. Similar to the exposure of the DC-firm when providing the futures market, the CPE/LDC will be 'locked into' the relationship with the original technology supplier when requiring services at contract execution. The CPEs/ LDC's dependence on the technology supplier will let the DC-firm exploit its monopoly position by overpricing the provision of spare parts and other services. By making both partners mutually dependent on each other - the DC-firm on the supply of countertrade goods at western quality levels and the CPEs/LDCs on the provision of after sales services and technological improvements - they credibly commit the reliability of their future conduct. Neither product will exploit the dependency of the other.

In order to see whether the above story is consistent with actual countertrade contracts consider Table 7 which looks at the relation between some of the contract features and the degree of tying. Recall that in countertrade 75 per cent of all exports to the CPEs/LDCs consist of technology and machinery and 52 per cent of countertrade goods are differentiated in design and quality. If tying is a response to incentive problems associated with technology trade on the one hand and the provision of a private futures market on the other. I expect to find the degree of tying to be related to the characteristics of trade flows. This is indeed the case. Countertrade contracts which involve a technology export to the CPEs/LDCs tend to have lower compensation ratios as compared to those contracts that do not consist of technology exports. The relationship is significant at the one per cent level. ${ }^{14}$ Similarly, when the western firm repurchases differentiated countertrade goods from the CPE/LDC the compensation ratio is either below or above 100 per cent. 55.2 per cent of all contracts in which the countertrade good is differentiated in design and/or quality have a compensation ratio below 100 per cent (as compared to 39.8 per cent when the countertrade goods are standardised). The degree of differentiation (see footnote 2 in Table 7 for definition) is used here as an indicator for whether the DC-firm had to make upfront investments for the successful introduction of the countertrade goods on western markets. It is assumed here that the less standardised the countertrade product the more marketing efforts the DC-firm will be required to undertake to provide the futures

\footnotetext{
14 The reason for this is that in general the technology that the DC-firm provides in the contract has a high transaction value so that already a small compensation ratio locks the DC-firm sufficiently into the relationship by hurting its profits in case of contractual hazards moving its incentives in the right direction.
} 
market. The association between the degree of differentiation of the countertrade goods and the compensation ratio is significant at the one per cent level.

TABLE 7

Incentives and Tying

\begin{tabular}{|c|c|c|c|c|c|}
\hline & & & & ensatio & \\
\hline & & & $<100 \%$ & $100 \%$ & $>100 \%$ \\
\hline Cha & racterist & f expo & & & \\
\hline investment, technology, know how & & 75.5 & 59.0 & 32.9 & 8.1 \\
\hline others & & 24.5 & 19.6 & 46.4 & 33.9 \\
\hline marginal significance & 0.000 & & & & \\
\hline Chi-Square Value & 34.97 & & & & \\
\hline Characteristics of countertrade goods & & & & & \\
\hline standardised $^{2}$ & & 48.2 & 39.8 & 48.1 & 12.0 \\
\hline differentiated ${ }^{3}$ & & 51.8 & 55.2 & 27.6 & 17.2 \\
\hline Marginal significance & 0.064 & & & & \\
\hline Chi-Square Value & 10.095 & & & & \\
\hline Contract duration ${ }^{4}$ & & & & & \\
\hline short-term & & 50.0 & 36.5 & 41.7 & 21.7 \\
\hline mid-term & & 42.6 & 62.2 & 31.6 & 6.1 \\
\hline long-term & & 7.4 & 58.8 & 29.4 & 11.8 \\
\hline Marginal significance & 0.0011 & & & & \\
\hline Chi-Square Value & 18.28 & & & & \\
\hline Risk shifting 5 & & & & & \\
\hline fixed price and quantity & & 43.0 & 39.4 & 42.4 & 18.2 \\
\hline fixed price, flexible quantity & & 10.9 & 38.9 & 38.9 & 22.2 \\
\hline fixed quantity, flexible price & & 7.8 & 68.0 & 28.0 & 4.0 \\
\hline flexible price and quantity & & 34.3 & 53.2 & 34.2 & 12.7 \\
\hline Marginal significance & 0.097 & & & & \\
\hline Chi-Square Value & 14.76 & & & & \\
\hline
\end{tabular}

Note: Numbers are row percentages.

${ }^{1}$ See footnote 1 and 2 in Table 2 for definition

2Judgment of countertrade specialist: scaling = standardised product in quality and design. standardised in quality but not design, standardised design but not quality.

${ }^{3}$ Not standardised product with respect to quality and design.

${ }^{4}$ Short-term: includes spot transactions and contracts with a time horizon of up to one year; mid-term: contracts with duration of up to 5 years; long-term contracts with duration of up to 10 years or infinite time horizon.

${ }^{3}$ Degree of price/quantity adjustment for countertrade goods over duration of contract.

Source: Sample of 230 countertrade contracts.

Alternatively, Table 7 looks also at whether the provision of a futures market can account for the tying feature of countertrade. Whether countertrade will be effective in shifting market uncertainty to the DC-firm will depend on two attributes of the insurance contract. First, on whether the time horizon of the contract is sufficiently long. The longer the duration of the contract the higher the risk for the DC-firm of unanticipated market changes and the more effectively will the CPEs/LDCs be able to plan their exports. 
Second, on whether the parties agree to fix prices and quantities of the countertrade goods over the duration of the contract or whether prices and quantities will be subject to renegotiation. When prices and quantities are fixed over the time horizon of the contract, the DC-firm absorbs the risk of future changes in market conditions, while if both prices and quantities are renegotiable the countertrading countries are less effectively insured against future market fluctuations. ${ }^{\text {is }}$ Both features, the duration of contract and the degree of price/ quantity adjustment over time are shown in Table 7 . The null hypothesis of independence between contract duration and risk shifting on the one hand and the compensation ratio on the other has been rejected by the Chi-square test at the one and ten per cent significance level, respectively.

\section{IMPLICATIONS FOR TRADE POLICY AND THE GATT}

This paper provides an empirical foundation of countertrade based on 230 contracts that have been signed between firms from OECD countries and CPEs and LDCs in the period between 1984 and 1988. The paper looks at whether evidence can be found in actual countertrade contracts that indicates gains from tying trade flows. The data indeed give some support for the view that tied trade might outperform untied ones which questions the common view that countertrade is an inefficient form of exchange. Tied trade might be superior to untied ones for the following reasons. First, countertrade might be used as a vehicle to change the terms of trade in the presence of market distortions thereby restoring price flexibility. Second, countertrade might be a response to moral hazard incentive problems that arise in technology trade on the one hand and in risk sharing arrangements on the other. In other words, because there is a two-way flow the two parties involved in the contract are more equally exposed, thereby preventing opportunistic behaviour when it comes to renegotiation during contract execution. Moreover, the ex post 'hold up' problem during contract execution between the $\mathrm{CPE} / \mathrm{LDC}$ as the producer and the DC-firm as the provider of a private futures market might explain why CPEs and LDCs use countertrade rather than traditional unilateral transactions as an export promoting policy. Countertrade then promotes exports of countertrading countries in two different ways. First, by changing the terms of trade, countertrade can be viewed as an export subsidy that is financed by the DC-firm. ${ }^{16}$ Assuming that the CPEs/LDCs face a reputational barrier to entry on western markets, the subsidy - by lowering the prices for the countertrade goods - makes western consumers learn faster the true quality of the goods

\footnotetext{
${ }^{15}$ For the factors determining the degree of risk shifting see Amann and Marin (1990).

${ }^{16}$ For countertrade as an import-financed export subsidy see Amann and Marin (1989).
} 
coming from these regions by giving them an incentive to start to purchase them. ${ }^{17}$ Second, by its tying feature countertrade provides the firms in OECD countries with an incentive to invest in informing western consumers about the true quality of the countertrade goods thereby assisting the LDCs/CPEs in overcoming the entry barrier in western markets.

The implications from what has been said in the paper are the following Countertrade is not likely to disappear in the near future. Since countertrade is not a response to weaknesses in the planning system but a second-best outcome in the presence of market imperfections, the former CPEs can be expected to continue to use countertrade even after transformation to a market economy. The extent to which countertrade arrangements will prevail in the future will depend on whether the economic transformation in Eastern Europe will allow these countries to solve their foreign debt problems on the one hand and on the extent of which other institutional forms will replace the tying arrangements as a way of dealing with the incentive problems associated with technology trade and risk sharing. A substantial permanent reduction in foreign debt will most likely also reduce the need for countertrade as an insurance against fluctuations in future foreign exchange earnings. ${ }^{18}$ The removal of the foreign ownership constraint in the former CPEs, in turn, will induce some shift from tying arrangements to transactions within firms like joint ventures and foreign direct investments in those cases when the latter prove to have comparative institutional advantages over tying arrangements in dealing with the incentive issues raised in the paper.

\section{REFERENCES}

Akerlof, G.A. (1970), The Market for 'Lemons': Quality Uncertainty and the Market Mechanism, Quarterly Journal of Economics, 488-500.

Amann, E. and D. Marin (1989), Barter in International Trade: A Rationale, Institute for Advanced Studies, Research Memorandum No. 257, Vienna.

Amann, E. and D. Marin (1990), Long-Term Contracts in International Trade, Centre for Economic Policy Research, Discussion Paper No. 413, London.

Banks, G. (1983), The Economics and Politics of Countertrade, The World Economy 2, 159-182. Caves, R. and D. Marin (1990), Countertrade Transactions: Rationales, Structure, Outcomes, Harvard University and Institute for Advanced Studies, Cambridge-Vienna, mimeo.

Chan, R. and M. Hoy (1990), East-West Joint Ventures and Buy-Back Contracts, University of Guelph, Ontario, mimeo.

Crawford, V. (1988), Long-Term Relations Governed by Short-Term Contracts, American Economic Review, 78, 3, 485-499.

\footnotetext{
${ }^{17}$ It is assumed here that the products that are subsidised through countertrade have an underlying comparative advantage. For the conditions under which an export subsidy might be welfare improving in face of an informational barrier to entry see Grossman/Horn (1988) and Mayer (1984).

${ }_{18}$ However, there is a hysteresis phenomenon present here. Because these countries have incurred fixed costs to build up knowledge of countertrade they will not readily leave it even when the reason for it has disappeared.
} 
Czinkota, M.R. (1987), The Role of Countertrade in Future GATT Deliberations, in: Korth, Ch. (ed.), International Countertrade, 169-177.

Economic Commission for Europe (1983), Compensation Trade in the ECE Region: A Survey of Quantitative Estimates, United Nations Economic and Social Council, TRADE/AC, 19/R.1.

Farrel, J. and C. Shapiro (1989), Optimal Contracts with Lock-In, American Economic Review, 79, 1, 51-68.

Gadbaw, R.M. (1983), The Implications of Countertrade under the General Agreement on Tariffs and Trade, Journal of Comparative Business and Capital Market Law, 5, 355-365.

Goldstein, E. (1984), A Theoretical Model of Countertrade, Research Paper No. 8404, Federal Reserve Bank of New York.

Greenaway, D. (1990), Trade Related Investment Measures: Political Aspects and Issues for GATT, The World Economy, 13, 3.

Grossman, S. and O.D. Hart (1986), The Costs and Benefits of Ownership: A Theory of Vertical Integration, Journal of Political Economy.

Grossman, G.M. and H. Horn (1988), Infant-Industry Protection Reconsidered: The Case of Informational Barriers to Entry, Quarterly Journal of Economics, 4, 767-787.

Group of Thirty (1985), Countertrade in the World Economy, New York.

Guisinger, St. (1987), Investment Related to Trade. In: Finger, M. and Olechowski, A. (eds.): The Uruguay Round. A Handbook for the Multilateral Trade Negotiations, The World Bank, Washington, 217-255.

Klein, B., R.C. Crawford and A.A. Alchian (1978), Vertical Integration. Appropriate Rents and the Competitive Contracting Process. Journal of Law and Economics, 21, 2, 297-326.

Korth, C.M. (ed.), (1987), International Countertrade, Westport, Quorum Books.

Marin, D. (1988), Assessing Countertrade, Report to the European Commission, Florence.

Mayer, W. (1984), The Infant-Export Industry Argument, Canadian Journal of Economics, 12, 249-269.

Organisation for Economic Cooperation and Development (1981), East-West Trade: Recent Developments in Countertrade, Paris, OECD.

Organisation for Economic Cooperation and Development (1985), Countertrade: Developing Country Practices, Paris, OECD.

Parsons, J.E. (1985), A Theory of Countertrade Financing of International Business, Sloan School of Management, MIT Working Paper No. 1632-85.

Rey, P. and B. Salanie (1990), Long-Term, Short-Term and Renegotiation: On the Value of Commitment in Contracting, Econometrica, 58, 3, 597-619.

Stiglitz, J.E. (1974), Incentives and Risk Sharing in Sharecropping. Review of Economic Studies, $42,2,219-56$.

Tirole, J. (1988), The Theory of Industrial Organization, Cambridge, Massachusetts, MIT Press. Williamson, O. (1983), Credible Commitments: Using Hostages to Support Exchange, American Economic Review 4, 519-540.

Williamson, O. (1985), The Economic Institution of Capitalism, New York, Free Press. 